\title{
1 Accuracy and performance of the WHO 2015 and WHO 2019 HIV testing strategies
}

\section{2 across epidemic settings}

3 Short title: Accuracy and performance of WHO recommended HIV testing strategies

4 Jeffrey W Eaton ${ }^{1 \mathcal{S}}$, Anita Sands², Magdalena Barr-DiChiara ${ }^{3}$, Muhammad S Jamil ${ }^{3}$, Rachel

5 Baggaley ${ }^{3}$, Beth A Tippett Barr ${ }^{4}$, Thokozani Kalua ${ }^{5}$, Andreas Jahn ${ }^{5,6}$, Mathieu Maheu-Giroux ${ }^{7}$,

6 Cheryl C Johnson ${ }^{3}$

$7 \quad{ }^{1}$ MRC Centre for Global Infectious Disease Analysis, School of Public Health, Imperial

$8 \quad$ College London, United Kingdom

${ }^{2}$ Regulation and Prequalification Department, World Health Organization, Geneva, Switzerland

${ }^{3}$ Global HIV, Hepatitis and STI Programmes, World Health Organization, Geneva, Switzerland

${ }^{4}$ US Centers for Disease Control and Prevention, Kisumu, Kenya

${ }^{5}$ Department of HIV and AIDS, Ministry of Health, Lilongwe, Malawi

${ }^{6}$ International Training and Education Center for Health, Department of Global Health, University of Washington, Seattle, USA

${ }^{7}$ Department of Epidemiology, Biostatistics, and Occupational Health, School of Population and Global Health, McGill University, Montreal, Canada

$\S$ Corresponding author: Jeffrey W Eaton

E-mail addresses of authors:

JWE: jeffrey.eaton@imperial.ac.uk

AS: sandsa@who.int

MBD: barrdichiaram@who.int

MJ: mjamil@who.int

RB: baggaleyr@who.int

BTB: btippettbarr@cdc.gov

TK: thokokalua@gmail.com

AJ: ajahn@itech-malawi.org

MMG: mathieu.maheu-giroux@mcgill.ca

33 Keywords: HIV diagnosis; testing strategy, testing algorithm, predictive values, accuracy

34 Word county: 3830 words

35 Abstract: 316 words

NOTE: This preprint reports new research that has not been certified by peer review and should not be used to guide clinical practice. 1 
medRxiv preprint doi: https://doi.org/10.1101/2021.03.31.21254700; this version posted April 6, 2021. The copyright holder for this preprint (which was not certified by peer review) is the author/funder, who has granted medRxiv a license to display the preprint in perpetuity. It is made available under a CC-BY-NC 4.0 International license .

\section{Abstract}

Background: WHO 2019 HIV testing guidelines recommended a standard HIV testing strategy consisting of three consecutively HIV-reactive test results on serology assays to diagnose HIV infection. National HIV programmes in high prevalence settings currently using the strategy consisting of only two consecutive HIV-reactive tests should consider when to implement the

41 new guideline recommendations.

42 Methods and Findings: We implemented a probability model to simulate outcomes of WHO

432019 and the two strategies recommended by WHO 2015 guidelines on HIV testing services.

44 Each assay in the strategy was assumed independently $99 \%$ sensitivity and $98 \%$ specificity, the

45 minimal thresholds required for WHO prequalification. For each strategy and positivity ranging

$4620 \%$ to $0.2 \%$, we calculated the number of false-negative, false-positive, and inconclusive

47 results; positive and negative predictive value (PPV, NPV); number of each assay used, and

48 testing programme costs. We found that the NPV was above $99.9 \%$ for all scenarios modelled.

49 Under the WHO 2015 two-test strategy, the PPV was below the 99\% target threshold when

50 positivity fell below 5\%. For the WHO 2019 strategy, the PPV was above 99\% for all positivity

51 levels. The number reported 'inconclusive' was higher under the WHO 2019 strategy.

52 Implementing the WHO 2019 testing strategy in Malawi, would require around 89,000 A3 tests

53 in 2021, compared to 175,000 A2 tests and over 4.5 million A1 tests per year. The incremental

54 cost of the WHO 2019 strategy was less than $2 \%$ in 2021 and declined to $0.9 \%$ in 2025.

55 Conclusions: As positivity among persons testing for HIV reduces below $5 \%$ in nearly all

56 settings, implementation of the WHO 2019 testing strategy will ensure that positive predictive

57 value remains above the 99\% target threshold, averting misdiagnoses and ART initiations

58 among HIV uninfected people. The incremental cost of implementing the WHO 2019 HIV testing 
medRxiv preprint doi: https://doi.org/10.1101/2021.03.31.21254700; this version posted April 6, 2021. The copyright holder for this preprint (which was not certified by peer review) is the author/funder, who has granted medRxiv a license to display the preprint in perpetuity. It is made available under a CC-BY-NC 4.0 International license .

59 strategy compared to the two-test strategy is negligible because the third assay accounts for a

60 small and diminishing share of total HIV tests. 
medRxiv preprint doi: https://doi.org/10.1101/2021.03.31.21254700; this version posted April 6, 2021. The copyright holder for this preprint (which was not certified by peer review) is the author/funder, who has granted medRxiv a license to display the preprint in perpetuity. It is made available under a CC-BY-NC 4.0 International license .

\section{Introduction}

62 Providing accurate, timely, and affordable HIV diagnosis at the point of care is a critical first step

63 towards delivering HIV treatment and prevention services. To establish HIV diagnosis, the

64 World Health Organization (WHO) recommends HIV testing strategies using multiple HIV

65 serology assays including rapid diagnostic tests (RDTs) and enzyme-immunoassays (EIAs)

$66[1,2]$. Each assay should have a sensitivity of greater than or equal to $99 \%$ (the assay is reactive

67 for at least 99 out of 100 truly HIV positive specimens) and specificity of greater than or equal to

$6898 \%$ (the assay is non-reactive for at least 98 out of 100 truly HIV negative specimens), the

69 minimum thresholds for approval through the WHO prequalification procedure $[3,4]$.

70 To ensure accurate diagnosis in all settings, WHO has previously recommended differentiated

71 HIV testing strategies according to the prevalence of HIV in the population being tested [2,4]. In

72 'high' HIV prevalence populations with prevalence above 5\%, two consecutively HIV-reactive

73 test results were recommended to diagnose HIV; when prevalence was below $5 \%$, three

74 consecutively HIV-reactive test results were recommended. This threshold at $5 \%$ was

75 established to ensure that the combination of assays utilized in a testing strategy have at least

$7699 \%$ positive predictive value (PPV)—that is at least 99 out of every 100 individuals classified as

77 HIV positive are truly HIV positive, or fewer than 1 false-positive per 100 HIV positive individuals

78 tested - when assays attain the minimum $98 \%$ specificity requirement [4].

79 When choosing a testing strategy, HIV programmes have typically used national HIV population

80 prevalence (greater or less than 5\%) as a proxy to guide whether to implement a 'two-test' or

81 'three-test' strategy. However, as awareness of HIV status has reached high levels, positivity

82 amongst persons presenting for HIV testing services (HTS) has declined steeply in recent

83 years. Even in the highest HIV prevalence settings in southern and eastern Africa, the positivity

84 is below the $5 \%$ threshold and expected to further decline in future given high ART coverage 
medRxiv preprint doi: https://doi.org/10.1101/2021.03.31.21254700; this version posted April 6, 2021. The copyright holder for this preprint (which was not certified by peer review) is the author/funder, who has granted medRxiv a license to display the preprint in perpetuity. It is made available under a CC-BY-NC 4.0 International license.

85 and estimated low HIV incidence [5]. A 2018 policy review found that only $25 \%$ of national HIV

86 testing guidelines were fully adherent with WHO recommendations on HIV testing strategies [6].

87 Despite declining HIV positivity, few programmes have transitioned from using two HIV-reactive

88 test results to three HIV-reactive test results to maintain high PPV.

89 Responsive to declining positivity and the challenges implementing differentiated guideline

90 recommendations, the 2019 revision of the WHO Consolidated Guidelines on HIV Testing

91 Services recommended a single 'standard' HIV testing strategy for all settings in which HIV

92 testing is conducted. The WHO 2019 testing strategy recommended HIV-reactive results from

93 three consecutive serology assays and simplified the steps for adjudicating cases with

94 discrepant results on serially conducted tests (Figure 1). National HIV programmes should now

95 consider when and how to implement new recommendations to transition from a 'two-test' to the

96 'three-test' testing strategy, including the potential implications for accuracy and misdiagnosis,

97 and programme and commodities costs.

98 To support decision making, we analysed the performance of the WHO 2019 standard HIV

99 testing strategy compared to the previous two-test and three-test testing strategies with respect

100 to PPV, negative predictive value (NPV), and the number of HIV-inconclusive results returned at

101 a range of HIV positivity values. Second, we calculated cost and commodity considerations of

102 the respective testing strategies using epidemiologic and HIV testing programme data from

103 Malawi as an example case study.

\section{Methods}

105 Model

106 We implemented a probability model to deterministically simulate the expected outcomes of the

107 WHO 2019 HTS Guidelines and the two testing strategies recommended by WHO 2015 HTS 
medRxiv preprint doi: https://doi.org/10.1101/2021.03.31.21254700; this version posted April 6, 2021. The copyright holder for this preprint (which was not certified by peer review) is the author/funder, who has granted medRxiv a license to display the preprint in perpetuity. It is made available under a CC-BY-NC 4.0 International license .

108 Guidelines, including stipulated repetition of one or more assays in the case of discrepant test

109 results (Figure 1) [4,7]. We refer to the 'high' and 'low' prevalence testing strategies as the 'two-

110 test' and 'three-test' strategies, respectively. The numbers refer to the sequential assays

111 required for an HIV-positive diagnosis, and not the overall number of assays needed in the

112 respective strategy, as the two-test testing strategy also requires a third assay to be available in

113 the event of discrepant results (Figure 1A) [4].

114 Each assay in the testing strategy was assumed to be independent and perform with $99 \%$

115 sensitivity and $98 \%$ specificity, the minimum performance requirements for WHO

116 prequalification $[7,8]$. WHO recommends that any initially discrepant $A 1+/ A 2-$ cases be

117 repeated immediately using assay $1(\mathrm{~A} 1)$. We assumed that repetition of $A 1$ will resolve the

118 discrepancy in $80 \%$ of cases (e.g. with presumed 'use error' or other random error resulting in

119 initially discrepant results), while the A1+/A2-/A1+ discrepancy persisted $20 \%$ of the time (due

120 to false reactivity for A1+ for truly HIV negative persons or low antibody levels not detected with

121 A2 for truly HIV positive persons). Case that were twice discrepant (initial: A1+ / A2-; repeat:

122 A1+ / A2-) under the WHO 2015 three-test testing strategy were classified as 'HIV negative'.

123 (This outcome does not occur under the WHO 2019 strategy because A2 is not repeated. Such

124 cases $\mathrm{A} 1+/ \mathrm{A} 2-/ \mathrm{A} 1+$ are reported HIV-inconclusive after repeat $\mathrm{A} 1+$ and recommended to

125 retest after 14 days).

126 Input parameters to the model were: (1) Number individuals tested for HIV, (2) proportion truly

127 HIV positive among those tested, (3) WHO HIV testing strategy (two-test or three-test), (4)

128 sensitivity of each assay (assumed 99\%), (5) specificity of each assay (assumed 98\%), (6)

129 probability that repetition of false-reactive A1 ( 1 + for a truly HIV-negative person) is non-

130 reactive upon repetition of $\mathrm{A} 1$ (assumed $80 \%$ ), and (7) HIV testing costs (including commodities,

131 site overheads, staff salaries, and other). 
medRxiv preprint doi: https://doi.org/10.1101/2021.03.31.21254700; this version posted April 6, 2021. The copyright holder for this preprint (which was not certified by peer review) is the author/funder, who has granted medRxiv a license to display the preprint in perpetuity. It is made available under a CC-BY-NC 4.0 International license .

133 The model produced the following outcomes: the absolute number of individuals ruled HIV-

134 positive, HIV-negative, and HIV-inconclusive (who are asked to return after 14 days to undergo

135 testing again), observed HIV-positivity amongst individuals presenting for HTS, number false-

136 positive and number false-negative diagnoses, positive and negative predictive values, number

137 of $\mathrm{A} 1, \mathrm{~A} 2$, and $\mathrm{A} 3$ products utilized, and estimated total HIV testing costs.

138 Costs were indicative of current HTS programme costs in many low- and middle-income (LMIC)

139 settings and were 'fully loaded' costs including consumables, staff, facilities, and programme

140 management. We assumed an average service delivery cost of US\$2.00 per client tested plus

141 the unit cost of each assay used in the algorithm. The unit cost reported in the WHO Global

142 Price Reporting for a typical product used as $\mathrm{A} 1$ was around $\$ 0.80$ per test compared to around

$143 \$ 1.60$ for a typical product used as A2 [9]. Supply chain monitoring data from Malawi indicate

144 that around $95 \%$ of $\mathrm{A} 1$ consumables are used for client testing with the remaining $5 \%$ for other

145 purposes such as quality assurance, proficiency testing, and loss. For A2 products, used only

146 after an HIV-reactive A1 result, around $70 \%$ are used for client testing and $30 \%$ for other

147 purposes [10]. Accounting for these factors and other per-test consumables and staff

148 expenditures, we assumed US\$1.30 for each A1 utilized, $\$ 2.30$ for each A2 utilized, and

149 US\$2.50 per A3 utilized. Taken together, the cost was around \$3.50 per HIV-negative client

150 tested and $\$ 5.60$ to $\$ 8.10$ per HIV-positive person tested. For cases initially reported as 'HIV-

151 inconclusive', we accounted for testing commodities and cost for retesting after 14 days, but did

152 not count the HIV status reported at repeat testing in calculations for number classified positive,

153 negative, PPV, or NPV because the primary objective of the HIV testing strategy is to return the

154 accurate HIV testing result at the clinical encounter.

155 Analyses 
medRxiv preprint doi: https://doi.org/10.1101/2021.03.31.21254700; this version posted April 6, 2021. The copyright holder for this preprint (which was not certified by peer review) is the author/funder, who has granted medRxiv a license to display the preprint in perpetuity. It is made available under a CC-BY-NC 4.0 International license .

156 We conducted two analyses. First, we simulated the expected HIV testing outcomes per

157100,000 individuals tested using either the WHO 2019, WHO 2015 two-test or WHO 2015 three-

158 test strategies for true positivity ranging from $20 \%$ to $0.2 \%$. We assessed (1) whether each test

159 strategy achieved above the 99\% threshold for PPV and NPV when assuming assays

160 performed at the minimum level required for WHO prequalification, (2) the number of HIV-

161 inconclusive results returned, and (3) the number of tests and total HTS cost.

162 Secondly, we used HIV epidemic estimates and projections and HIV testing programme data

163 from Malawi to understand the consequences of changes in HIV testing scale and positivity over

164 time on expected HIV testing programme outcomes.

165 We used 2020 national HIV estimates for Malawi submitted to UNAIDS to extract estimates for

166 the adult (15+) population over the period 2000 to 2025 for the indicators: number of people

167 living with HIV (PLHIV), number aware of HIV status and number on ART, and number of HIV

168 tests conducted, number of persons testing positive for HIV, and number persons diagnosed

169 HIV positive for the first time. Estimates and projections for the number of PLHIV and number

170 on ART were estimated by the Malawi national HIV estimates working group using the

171 Spectrum and EPP models [11,12]. HIV testing programme outcomes over the period 2000 to

1722019 were estimated from household survey and HIV testing programme data input to the

173 Shiny90 model [13]. Projections for the period 2020 through 2025 assumed that the 2019 rates

174 of HIV testing by age, sex, HIV status, and ART status would continue into the future. We input

175 the estimates for the annual number of tests conducted by HIV status into the HIV testing

176 strategy model to estimate the expected HIV testing programme outcomes had the two-test or

177 WHO 2019 testing strategy been used, and assuming assay performance at the minimum level

178 to attain WHO prequalification. 
medRxiv preprint doi: https://doi.org/10.1101/2021.03.31.21254700; this version posted April 6, 2021. The copyright holder for this preprint (which was not certified by peer review) is the author/funder, who has granted medRxiv a license to display the preprint in perpetuity. It is made available under a CC-BY-NC 4.0 International license .

179 The Malawi HIV testing programme has implemented the high prevalence (two-test) testing

180 strategy for HIV diagnosis, but the simulated results do not represent actual HIV testing

181 programme outcomes for Malawi in at least two ways. Firstly, HIV testing programme data from

182 Malawi suggest improving accuracy over time following a programme of training and quality

183 assurance. Secondly, since 2011 Malawi has implemented retesting for verification of HIV

184 status of all HIV-positive persons before ART initiation [14], which is not included in our

185 simulation.

186 Results

187 Outcomes per 100,000 tested for range of HIV testing positivity

188 Table 1 summarizes model outcomes per 100,000 persons tested at $10 \%, 5 \%$, $1 \%$, and $0.5 \%$

189 true positivity amongst persons tested for HIV. The expected number of false-positive

190 classifications is substantially lower with the three-test and WHO 2019 testing strategies at

191 fewer than 1 false HIV-positive per 100,000 individuals tested compared to around 45 false-

192 positives per 100,000 individuals tested with the two-test strategy and does not vary

193 substantially with positivity (Table 1, Figure 2A). In contrast, the expected number of false-

194 negative classifications was proportional to the positivity from 100 false-negatives per 100,000

195 individuals tested at $10 \%$ positivity to 10 false-negative per 100,000 individuals tested at $1 \%$

196 positivity with the two-test strategy. The three-test or WHO 2019 testing strategy does not affect

197 the expected number of false-negative classifications.

198 The negative predictive value (NPV) was $99.9 \%$ or greater for all testing strategies at all

199 positivity levels, well above the 99\% threshold (Table 1, Figure 2B). Under the two-test strategy,

200 the PPV was above the $99 \%$ threshold when positivity amongst individuals being tested was

201 above 5\%, but declined rapidly as positivity decreased (Table 1, Figure 2B). At 1\% positivity, the

202 PPV was $95 \%$ under the two-test strategy and this decreased to $91 \%$ at $0.5 \%$ positivity and 
medRxiv preprint doi: https://doi.org/10.1101/2021.03.31.21254700; this version posted April 6, 2021. The copyright holder for this preprint (which was not certified by peer review) is the author/funder, who has granted medRxiv a license to display the preprint in perpetuity. It is made available under a CC-BY-NC 4.0 International license .

$81 \%$ at $0.2 \%$ positivity. With the three-test or WHO 2019 testing strategy, the PPV increased to $99.9 \%$ at $1 \%$ positivity and was well above the $99 \%$ threshold for all simulated levels of positivity.

The number of results reported as 'HIV-inconclusive', in which the client would be asked to return for retesting after 14 days, was substantially higher under the WHO 2019 testing strategy than either the three-test or two-test strategy. For example, using the WHO 2019 testing strategy at $5 \%$ positivity, there were $508(0.51 \%)$ HIV-inconclusive results per 100,000

210 individuals tested, compared to 124 per $100,000(0.12 \%)$ for the three-test strategy and 47.2

$211(0.05 \%)$ with the two-test strategy. The increased number reported as HIV-inconclusive through

212 the WHO 2019 testing strategy arose from two sources (Table 2). The majority arose when A1+

213 and A2- were discrepant, and the repeat A1 was HIV-reactive, which was reported as HIV-

214 inconclusive under the WHO 2019 testing strategy. Under the WHO 2015 testing strategies, A2

215 was repeated and would result in either proceeding to A3 or reporting HIV-negative. Secondly, 216 under the WHO 2019 testing strategy, cases that were reactive on each of the first two assays $217(\mathrm{~A} 1+/ \mathrm{A} 2+)$, then non-reactive on the third $(\mathrm{A} 3-)$ were reported HIV-inconclusive. Under the two218 test strategy, such individuals were reported HIV positive following $\mathrm{A} 1+\mathrm{A} 2+$, and when positivity 219 is below $5 \%$ the majority are false-positive misclassifications and are actually true negatives 220 (Table 2).

221 HIV testing commodities and programme costs

222 The number of A1 used per 100,000 tested was relatively similar and accounted for the majority

223 of tests used for all positivity levels because most clients are classified HIV-negative following

224 A1 and do not undergo further testing (Table 1, Figure 3A). The number of A2 required was the 225 same under the three-test and two-test strategies and increased with positivity. The number of 226 A2 was lower under the WHO 2019 testing strategy because A2 is not repeated following 
medRxiv preprint doi: https://doi.org/10.1101/2021.03.31.21254700; this version posted April 6, 2021. The copyright holder for this preprint (which was not certified by peer review) is the author/funder, who has granted medRxiv a license to display the preprint in perpetuity. It is made available under a CC-BY-NC 4.0 International license .

227 discrepant $\mathrm{A} 1$ and $\mathrm{A} 2$ results, which accounts for a substantial fraction of $\mathrm{A} 2$ usage under the

228 WHO 2015 testing strategies when positivity is low. The number of A3 required was much

229 greater for the three-test and WHO 2019 testing strategies, but even under these two testing

230 strategy the number of A2 required were much larger than A3. This was because a substantial

231 share of $\mathrm{A} 2$ are utilized on persons with discrepant $\mathrm{A} 1+/ \mathrm{A} 2-$ results, which are ultimately

232 classified HIV-negative and do not progress on to A3. The difference in consumption between

233 A2 and A3 increases as positivity declines.

234 At $10 \%$ positivity, the total cost for the WHO 2019 testing strategy was $6 \%$ higher than the two-

235 test strategy (Table 1; Figure 2C). The cost difference reduced considerably with declining

236 positivity due to the lower consumption of A2 and A3. For testing positivity below $1.5 \%$, the cost

237 for the WHO 2019 testing strategy was slightly lower than the cost for two-test strategy because

238 the reduced need for A2 outweighed the slight increase in A3 consumption.

\section{Estimated and projected changes in HTS outcomes: Malawi example}

240 Figure 4 summarizes estimates and projections for the number of adult PLHIV over the period

2412000 through 2025 in Malawi. The total adult PLHIV was projected to increase slightly through

2422025 as PLHIV survive longer on ART. However, the proportion of undiagnosed PLHIV declined

243 rapidly from an estimated $79 \%$ in 2005 to $33 \%, 10 \%$ and $5 \%$ in 2010,2019 and 2025 ,

244 respectively (Figure 4A). Consequently, despite large increases in the number tested for HIV

245 each year, the number of HIV diagnoses peaked in 2010 and is projected to continue to decline

246 (Figure 4B). This was reflected in rapidly declining positivity amongst clients tested. Before

2472010 , positivity in the testing program exceeded the population prevalence as symptomatic

248 PLHIV were more likely to present for testing (Figure 4C). But in 2019, the positivity of

249 individuals being tested for HIV declined to around 3.1\% compared to adult HIV prevalence of

$2509.5 \%$ and the positivity was projected to further decline in 2025 to $1.2 \%$ compared to $8.3 \%$ 
medRxiv preprint doi: https://doi.org/10.1101/2021.03.31.21254700; this version posted April 6, 2021. The copyright holder for this preprint (which was not certified by peer review) is the author/funder, who has granted medRxiv a license to display the preprint in perpetuity. It is made available under a CC-BY-NC 4.0 International license .

251 prevalence. The proportion of individuals diagnosed for the first time among all tested for HIV

252 was $1.2 \%$ in 2019 , declining to $0.5 \%$ in 2025 .

253 The consequences of declining positivity for expected HIV testing programme quality and costs

254 are consistent with those reported in Table 1 and Figure 2. The expected NPV is substantially 255 above the 99\% threshold at all times (Figure 5A). However, the PPV dropped below the 99\%

256 threshold in 2018 with the WHO 2015 two-test strategy and will decline to $97 \%$ in 2025 if each

257 assay performs at the minimum threshold required for WHO prequalification (Figure 5A). This

258 equates to expecting an average of around 1800 false positive diagnoses per year. In contrast,

259 the PPV remained above 99.9\% with the WHO 2019 testing strategy-fewer than 40 false

260 positive diagnoses per year. If the rates of HIV testing are maintained at current levels, an

261 estimated 89,000 tests of A3 would be required to implement the WHO 2019 testing strategy in

2622021 , declining to 64,000 in 2025 , compared to around 175,000 tests of A2 and over 4.5 million

263 tests of A1 in 2021 (Figure 5B). The incremental cost of the WHO 2019 testing strategy was

264 less than $2 \%$ in 2021, and declined to around 0.9\% in 2025 (Figure 5C).

\section{Discussion}

266 Positivity in testing programs has declined below 5\% even in countries with high HIV population

267 prevalence [5]. The 2019 WHO HIV testing strategy requires reactive results on three serially

268 conducted serology assays to diagnose HIV infection. This algorithm substantially reduced the

269 number of false-positive misdiagnoses at all levels of positivity in HIV testing programs. When

270 HIV assays perform at the minimum WHO pre-qualification threshold of $98 \%$ specificity, the

2712019 WHO HIV testing strategy ensured that fewer than 1 in 100 persons diagnosed with HIV

272 were false-positive, which was not the case for the two-test strategy used by many high

273 prevalence countries. 
medRxiv preprint doi: https://doi.org/10.1101/2021.03.31.21254700; this version posted April 6, 2021. The copyright holder for this preprint (which was not certified by peer review) is the author/funder, who has granted medRxiv a license to display the preprint in perpetuity. It is made available under a CC-BY-NC 4.0 International license .

274 The number of false-negative misdiagnoses reduced proportionally as positivity declined for HIV

275 under all three testing strategies. The WHO 2019 testing strategy also increased the expected

276 number of HIV-inconclusive results returned, for example from $0.04 \%$ under the two-test

277 strategy to $0.45 \%$ with the WHO 2019 testing strategy at $1 \%$ positivity. However, at low positivity

278 levels, increased HIV-inconclusive results arose primarily due to simplification of testing strategy

279 for persons who are initially discrepant, reducing opportunity for errors, and among individuals

280 who are truly HIV negative but would have been misclassified as HIV-positive under the two-test

281 strategy. Had those HIV-inconclusive individuals received a false-positive misdiagnosis under

282 the two-test testing strategy, the cost of misdiagnosis and life-long treatment would be

283 significant $[14,15]$.

284 The two-test and three-test testing strategies both require an A3 to be available, but the number

285 of A3 consumed is expectedly much greater with the 3-test strategy since it is deployed for all

286 individuals with reactive results for both A1 and A2 rather than only for those with discrepant

287 test results (i.e. A1 reactive but A2 non-reactive). However, the number A3 required remains

288 lower than A2 and the difference increases as positivity declines. This is because at low

289 positivity, a large number of A2 are utilized for discrepant A1+/A2- results, which are classified

290 as HIV negative by repeating $\mathrm{A} 1$ and do not proceed to A3.

291 Declining positivity amongst individuals who undergo HIV testing is a reflection of successful

292 scale-up and implementation of HIV programmes that have reduced the undiagnosed HIV

293 population [5]. Our case study of Malawi exemplifies the consequences for the HIV testing

294 program. While HIV population prevalence has declined slowly from $11 \%$ in 2005 to $9.5 \%$ in

295 2019, the positivity amongst individuals undergoing HIV testing fell steeply from 15\% to 3\% over

296 the same period. Assuming 98\% specificity for each assay used, the 2015 WHO two-test testing

297 strategy (designed for 'high prevalence' settings) was expected to perform below 99\% PPV

298 since 2018 in Malawi and a further decline in PPV was projected. To mitigate this, Malawi has 
medRxiv preprint doi: https://doi.org/10.1101/2021.03.31.21254700; this version posted April 6, 2021. The copyright holder for this preprint (which was not certified by peer review) is the author/funder, who has granted medRxiv a license to display the preprint in perpetuity. It is made available under a CC-BY-NC 4.0 International license .

pioneered quality testing initiatives, including verification testing (using the same two-test testing strategy in parallel) before ART initiation. Malawi service delivery data suggests steady improvements in testing accuracy which are reflected in a declining proportion of inconclusive results and discrepant verification testing results. While the true number of false-positive and

303 false-negative misdiagnosis is unknown in Malawi, the simulated results illustrate the 304 importance to consider the 2019 WHO testing strategy.

305 The incremental cost of switching to the WHO 2019 testing strategy was less than $2 \%$ of the 306 total HIV testing programme cost and will decline further in the future. The low and decreasing 307 incremental cost is because the large majority of HIV testing clients are HIV negative and do not 308 proceed past A1, which thus accounts for the largest share of HTS programme cost despite a 309 lower unit cost. Our analysis assumed that the incremental cost of switching to the WHO 2019 310 testing strategy was captured by the additional cost of delivering A3. However, in many settings 311 A3 is not routinely stocked at all testing locations and specimens with discrepant test results are 312 instead referred to laboratories for additional testing to confirm their HIV status. Additional 313 training and supply chain costs of switching to a three-test strategy in such settings are 314 uncertain. Incorporating a new A3 into the testing strategy would require training of all HTS 315 providers, but such training activities could be conducted routinely as part of programme 316 management, quality assurance, and implementation of other guideline changes. Resolving 317 more cases at the facility instead of requiring discrepant specimens to be sent to a laboratory 318 should also offset costs of transport, information management, and tracing clients to provide 319 results. We were not able to estimate the cost for this additional lab testing using the current 320 policy, but considerable delays in returning such results from the reference lab have highlighted 321 the challenges with this approach. Timing changes and shifts in the testing strategy alongside 322 other changes in updates to guidelines, log-books and integrated trainings can also increase 323 cost efficiencies. 
medRxiv preprint doi: https://doi.org/10.1101/2021.03.31.21254700; this version posted April 6, 2021. The copyright holder for this preprint (which was not certified by peer review) is the author/funder, who has granted medRxiv a license to display the preprint in perpetuity. It is made available under a CC-BY-NC 4.0 International license .

324 Consistent with WHO guidelines, we assumed that all tests in the algorithm were conducted

325 serially, except for the parallel replication of A1 and A2 following initial discrepant A1+/A2-. An

326 HIV diagnosis with the WHO 2019 testing strategy would require three finger pricks for clients

327 with a reactive $A 1$. There has been some consideration to conducting $A 2$ and $A 3$ in parallel

328 could reduce the additional finger prick. However, this could also lead to additional challenges

329 with the interpretation of discrepant test results and add substantial wastage of A3 since, as

330 positivity becomes lower, an increasing share of those progressing to A2 were false reactive to

331 A1 and classified as HIV negative on A1 repetition, and not progress to A3. For example, in

332 Malawi, parallel application of A2 and A3 would roughly double the number of A3 required.

333 There were two assumptions with limited empirical data to which our findings are potentially

334 sensitive: (1) that $80 \%$ of discrepant $A 1+/ A 2-$ would be correctly resolved upon replication of

335 the $A 1$ and $A 2$, while $20 \%$ would remain discrepant, and (2) that each assay in the testing

336 strategy is independent and performs at the minimum threshold for WHO prequalification,

337 namely $98 \%$ specificity. Our conclusions should be interpreted considering these limitations and

338 should be reevaluated as more evidence on these points becomes available.

339 Our modelling suggests that transitioning to the WHO 2019 HIV testing strategy, requiring three

340 reactive tests to diagnose HIV, ensures accuracy and quality of HIV diagnosis into the future

341 with minimal consequences for overall HIV testing programme costs. The alternative, without

342 adopting the strategy requiring three reactive tests to diagnose HIV, is increasing false positive

343 misdiagnoses as a proportion of all those newly diagnosed with HIV. This incurs unnecessary

344 lifelong ART costs for HIV negative persons [14,15], unquantified individual physical,

345 psychosocial and emotional harms of receiving a false positive HIV misdiagnosis [16,17], and

346 undermining confidence in the health system. While the WHO 2019 HIV testing strategy

347 ensures the fidelity of HIV diagnosis and subsequent care and treatment, the main determinant

348 of HIV testing programme cost is the overall scale if HIV testing and the number A1 conducted. 
medRxiv preprint doi: https://doi.org/10.1101/2021.03.31.21254700; this version posted April 6, 2021. The copyright holder for this preprint (which was not certified by peer review) is the author/funder, who has granted medRxiv a license to display the preprint in perpetuity. It is made available under a CC-BY-NC 4.0 International license .

\section{References}

350 1. Global programme on AIDS. Recommendations for the selection and use of HIV antibody tests. Wkly Epidemiol Rec Relev Epidemiol Hebd World Heal Organ. 1992;67: 145-149.

352 2. Joint United Nations Programme on HIV/AIDS (UNAIDS)-WHO. Revised recommendations for the selection and use of HIV antibody tests. Wkly Epidemiol Rec.

3. World Health Organization. Selecting and purchasing HIV, HBsAg and HCV in vitro diagnostics. 2021 [cited 23 Feb 2021]. Available: https://www.who.int/diagnostics_laboratory/procurement/purchase/en/

4. World Health Organization. Consolidated guidelines on HIV testing services. 2015 p. 193. Available: http://apps.who.int/iris/bitstream/10665/179870/1/9789241508926_eng.pdf

5. Giguère K, Eaton JW, Marsh K, Johnson LF, Johnson CC, Ehui E, et al. Trends in knowledge of HIV status and efficiency of HIV testing services in sub-Saharan Africa, 2000-20: a modelling study using survey and HIV testing programme data. Lancet HIV. 2021 [cited 8 Mar 2021]. doi:10.1016/S2352-3018(20)30315-5

6. Fonner VA, Sands A, Figueroa C, Baggaley R, Quinn C, Jamil MS, et al. Country adherence to WHO recommendations to improve the quality of HIV diagnosis: a global policy review. BMJ Glob Heal. 2020;5: e001939. doi:10.1136/bmjgh-2019-001939

367 7. World Health Organization. Consolidated guidelines on HIV testing services 2019. 2019 [cited 23 Feb 2021] p. 261. Available: 
medRxiv preprint doi: https://doi.org/10.1101/2021.03.31.21254700; this version posted April 6, 2021. The copyright holder for this preprint (which was not certified by peer review) is the author/funder, who has granted medRxiv a license to display the preprint in perpetuity. It is made available under a CC-BY-NC 4.0 International license .

to WHO prequalification - Diagnostic Assessment: TSS-1: Human Immunodeficiency Virus (HIV) rapid diagnostic tests for professional and/or self-testing. 2016 [cited 15 Nov 2018]. Available: http://apps.who.int/iris/bitstream/handle/10665/251857/9789241511742eng.pdf

375

9. World Health Organization. Global Price Reporting Mechnism. 2017 [cited 10 Dec 2017]. Available: https://apps.who.int/hiv/amds/price/hdd

10. Government of Malawi Ministry of Health. Integrated HIV Program Report OctoberDecember 2017. Lilongwe; 2018.

11. Stover J, Glaubius R, Mofenson L, Dugdale CM, Davies MA, Patten G, et al. Updates to the Spectrum/AIM model for estimating key HIV indicators at national and subnational levels. AIDS. 2019;33: S227-S234. doi:10.1097/QAD.0000000000002357

12. Eaton JW, Brown T, Puckett R, Glaubius R, Mutai K, Bao L, et al. The Estimation and Projection Package Age-Sex Model and the r-hybrid model: new tools for estimating HIV incidence trends in sub-Saharan Africa. AIDS. 2019;33 Suppl 3: S235-S244. doi:10.1097/QAD.0000000000002437

13. Maheu-Giroux M, Marsh K, Doyle CM, Godin A, Lanièce Delaunay C, Johnson LF, et al. National HIV testing and diagnosis coverage in sub-Saharan Africa. AIDS. 2019;33:

S255-S269. doi:10.1097/QAD.0000000000002386

14. Eaton JW, Johnson CC, Gregson S. The Cost of Not Retesting: Human Immunodeficiency Virus Misdiagnosis in the Antiretroviral Therapy "Test-and-Offer" Era. Clin Infect Dis. 2017;65. doi:10.1093/cid/cix341 
HIV retesting for verification in Africa. PLoS One. 2019;14.

16. Bhattacharya R, Barton S, Catalan J. When good news is bad news: Psychological impact of false positive diagnosis of HIV. AIDS Care - Psychol Socio-Medical Asp

17. Johnson CC, Dalal S, Baggaley R, Taegtmeyer M. A public health approach to addressing and preventing misdiagnosis in the scale-up of HIV rapid testing programmes. Journal of the International AIDS Society. International AIDS Society; 2017. 
medRxiv preprint doi: https://doi.org/10.1101/2021.03.31.21254700; this version posted April 6, 2021. The copyright holder for this preprint (which was not certified by peer review) is the author/funder, who has granted medRxiv a license to display the preprint in perpetuity.

It is made available under a CC-BY-NC 4.0 International license .

403

404

405
406

407

408

409

410

Table 1. HIV testing strategy outcomes per 100,000 tested for $10 \%, 5 \%, 1 \%$, and $0.5 \%$ true positivity among clients presenting for HIV testing

\begin{tabular}{|c|c|c|c|c|c|c|}
\hline & \multicolumn{3}{|c|}{$10 \%$ positivity } & \multicolumn{3}{|c|}{$5 \%$ positivity } \\
\hline & 2-test & 3-test & WHO 2019 & 2-test & 3-test & WHO 2019 \\
\hline HIV-negative classifications & 90,022 & 90,049 & 89,712 & 94,968 & 94,985 & 94640 \\
\hline HIV-positive classifications & 9922 & 9781 & 9704 & 4985 & 4891 & 4852 \\
\hline HIV-inconclusive & 55 & 170 & 584 & 47 & 124 & 508 \\
\hline Observed positivity & $9.93 \%$ & $9.80 \%$ & $9.76 \%$ & $4.99 \%$ & $4.90 \%$ & $4.88 \%$ \\
\hline False HIV-positive & 43.1 & 0.86 & 0.72 & 45.4 & 0.91 & 0.76 \\
\hline False HIV-negative & 100.4 & 119.8 & 101.0 & 50.2 & 59.9 & 50.5 \\
\hline PPV of entire testing strategy & $99.6 \%$ & $>99.9 \%$ & $>99.9 \%$ & $99.1 \%$ & $>99.9 \%$ & $>99.9 \%$ \\
\hline NPV of entire testing strategy & $99.9 \%$ & $99.9 \%$ & $99.9 \%$ & $99.9 \%$ & $99.9 \%$ & $99.9 \%$ \\
\hline Assay 1 used & 101,918 & 102,033 & 102,447 & 101,959 & 102,036 & 102,419 \\
\hline Assay 2 used & 13,583 & 13,663 & 11,896 & 8,772 & 8,811 & 6,948 \\
\hline Assay 3 used & 365 & 10,022 & 10,033 & 375 & 5,035 & 5,037 \\
\hline \multirow[t]{3}{*}{ Cost (US\$) } & $\$ 385,143$ & $\$ 409,869$ & $\$ 407,282$ & $\$ 374,144$ & $\$ 386,155$ & $\$ 383,216$ \\
\hline & \multicolumn{3}{|c|}{$1 \%$ positivity } & \multicolumn{3}{|c|}{$0.5 \%$ positivity } \\
\hline & 2-test & 3-test & WHO 2019 & 2-test & 3-test & WHO 2019 \\
\hline HIV-negative classifications & 98,924 & 98,934 & 98582 & 99,419 & 99,427 & 99075 \\
\hline HIV-positive classifications & 1035 & 979 & 971 & 542 & 490 & 486 \\
\hline HIV-inconclusive & 41 & 87 & 446 & 40 & 83 & 439 \\
\hline Observed positivity & $1.04 \%$ & $0.98 \%$ & $0.98 \%$ & $0.54 \%$ & $0.49 \%$ & $0.49 \%$ \\
\hline False HIV-positive & 47.4 & 0.95 & 0.79 & 47.60 & 0.95 & 0.80 \\
\hline False HIV-negative & 10.0 & 12.0 & 10.1 & 5.0 & 6.0 & 5.0 \\
\hline PPV of entire testing strategy & $95.4 \%$ & $99.9 \%$ & $99.9 \%$ & $91.2 \%$ & $99.8 \%$ & $99.8 \%$ \\
\hline NPV of entire testing strategy & $>99.9 \%$ & $>99.9 \%$ & $>99.9 \%$ & $>99.9 \%$ & $>99.9 \%$ & $>99.9 \%$ \\
\hline Assay 1 used & 101,991 & 102,038 & 102,397 & 101,995 & 102,038 & 102,394 \\
\hline Assay 2 used & 4,922 & 4,930 & 2,990 & 4,441 & 4,445 & 2,495 \\
\hline Assay 3 used & 382 & 1,045 & 1,039 & 383 & 547 & 540 \\
\hline Cost (US\$) & $\$ 365,345$ & $\$ 367,184$ & $\$ 363,963$ & $\$ 364,245$ & $\$ 364,813$ & $\$ 361,556$ \\
\hline
\end{tabular}

NPV: negative predictive value; PPV: positive predictive value. Note: 2-test and 3-test denotes the number of consecutive HIV reactive tests to provide an HIV-positive diagnosis under the WHO 2015 guidelines 'high prevalence' and 'low prevalence' strategies, respectively, not number of tests required by the strategy. Specimens with repeated discrepant test results under the 2-test strategy proceed to a third assay. Specimens with repeat discrepant test results on the first two tests are ruled negative. In the 'WHO 2019' testing strategy, only A1 is repeated. 
medRxiv preprint doi: https://doi.org/10.1101/2021.03.31.21254700; this version posted April 6, 2021. The copyright holder for this preprint (which was not certified by peer review) is the author/funder, who has granted medRxiv a license to display the preprint in perpetuity. It is made available under a CC-BY-NC 4.0 International license .

411 Table 2. True HIV status for persons classified as 'HIV-inconclusive' under the WHO 2019 HIV 412 testing strategy. All results per 100,000 persons tested.

413

\begin{tabular}{lccccccc}
\hline & \multicolumn{3}{c}{ Testing Strategy Result Given } & \multicolumn{4}{c}{ Positivity } \\
& 2-test & 3-test & WHO & $10 \%$ & $5 \%$ & $1 \%$ & $0.5 \%$ \\
\hline Total inconclusive & & & & 584 & 508 & 446 & 439 \\
True HIV-negative & & & & $388(66 \%)$ & $410(81 \%)$ & $427(96 \%)$ & $429(98 \%)$ \\
True HIV-positive & & & & $196(34 \%)$ & $98(19 \%)$ & $20(4 \%)$ & $10(2 \%)$ \\
\hline Total A1+ / A2- / A1+ & & & & 451 & 421 & 398 & 395 \\
True HIV-negative & Rep. A2 & Rep. A2 & INC & $353(78 \%)$ & $372(88 \%)$ & $388(98 \%)$ & $390(99 \%)$ \\
True HIV-positive & Rep. A2 & Rep. A2 & INC & $98(22 \%)$ & $49(12 \%)$ & $10(2 \%)$ & $5(1 \%)$ \\
\hline Total A1+ / A2+ / A3- & & & & 133 & 86 & 49 & 44 \\
True HIV-negative & False pos. & INC & INC & $35(26 \%)$ & $37(43 \%)$ & $39(80 \%)$ & $39(89 \%)$ \\
True HIV-positive & Corr. pos. & INC & INC & $98(74 \%)$ & $49(57 \%)$ & $10(20 \%)$ & $5(11 \%)$ \\
\hline
\end{tabular}
Rep. A2 = Under the WHO 2015 HIV testing strategies (2-test and 3-test), the A2 test is repeated.; INC = 415 Inconclusive HIV test result returned with instruction to return after 14 days for retesting.; False pos. = A false 416 positive HIV diagnosis is returned under the WHO 2015 2-test strategy; Corr. pos. = A correct HIV positive diagnosis 417 is returned under the WHO 2015 2-test strategy. 
A

WHO 2015 'high prevalence' testing strategy (two-test)

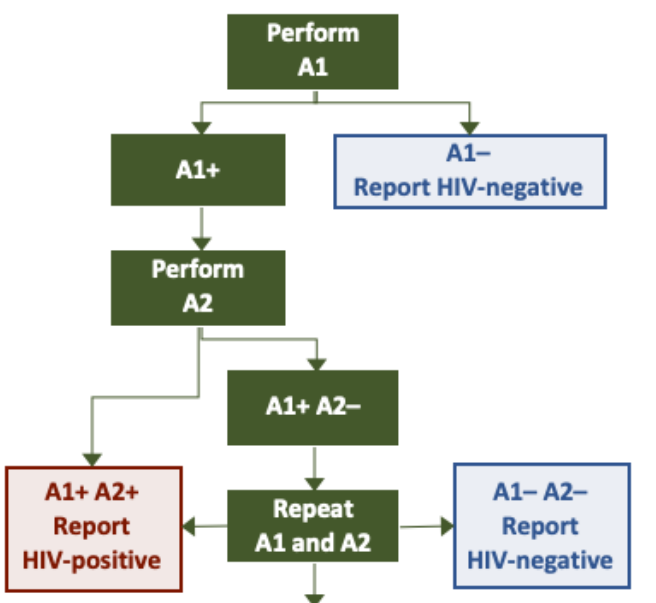

A1+ A2-
B

WHO 2015 'low prevalence' testing strategy (three-test)

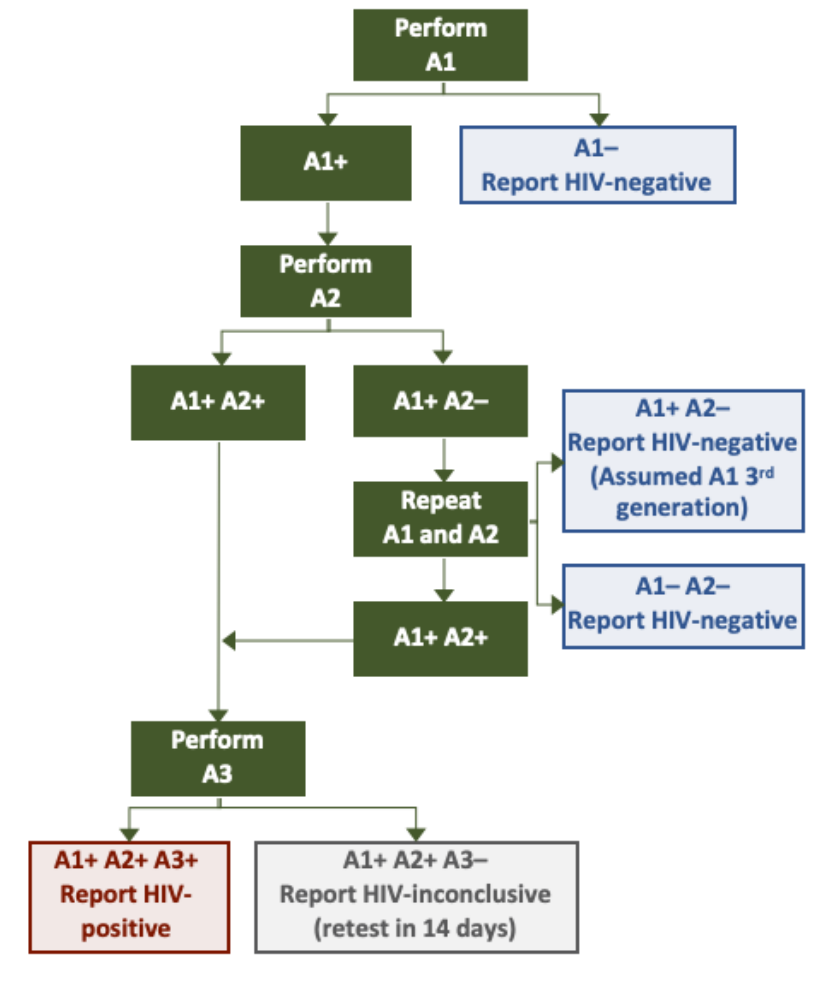

C

WHO 2019 HIV testing strategy

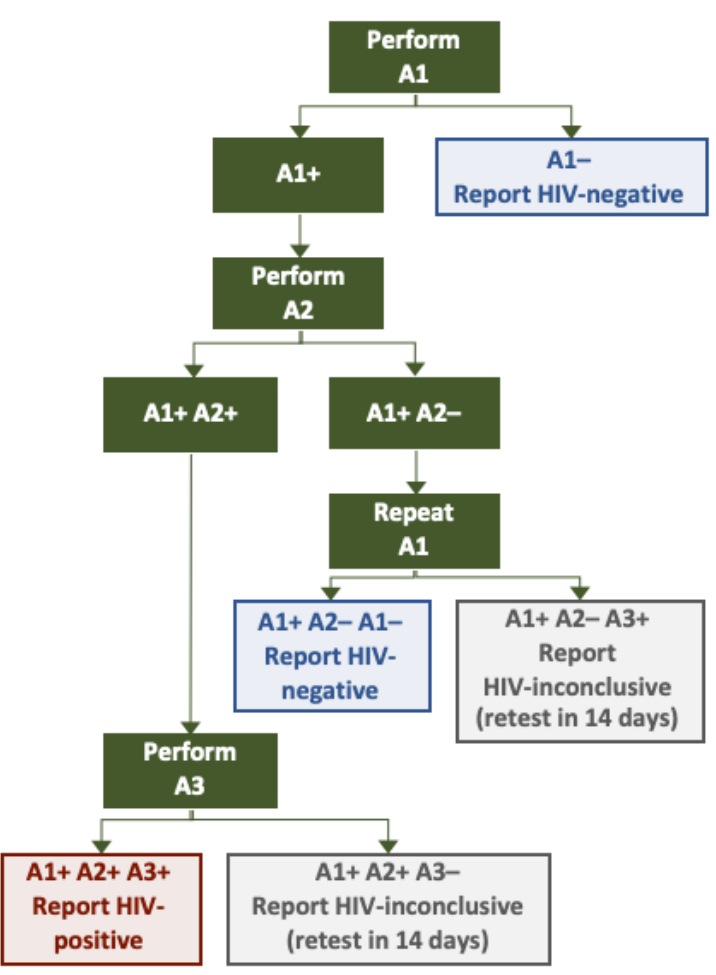

Figure 1. HIV testing strategies modelled. (A) and (B) are redrawn following WHO Consolidated Guidelines on HIV Testing Services 2015 Figures 7.2 and 7.3 [4]. (A) and (B) assume a $3^{\text {rd }}$ generation A1 assay is used. (C) is redrawn following WHO Consolidated Guidelines on HIV Testing Services 2019 Figure 8.3 [7]. 
A

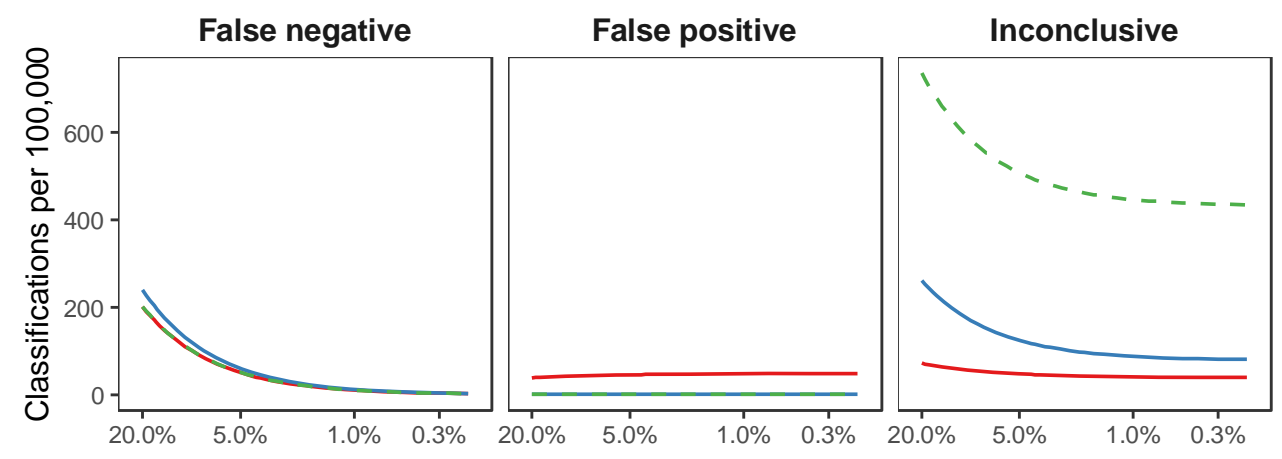

B

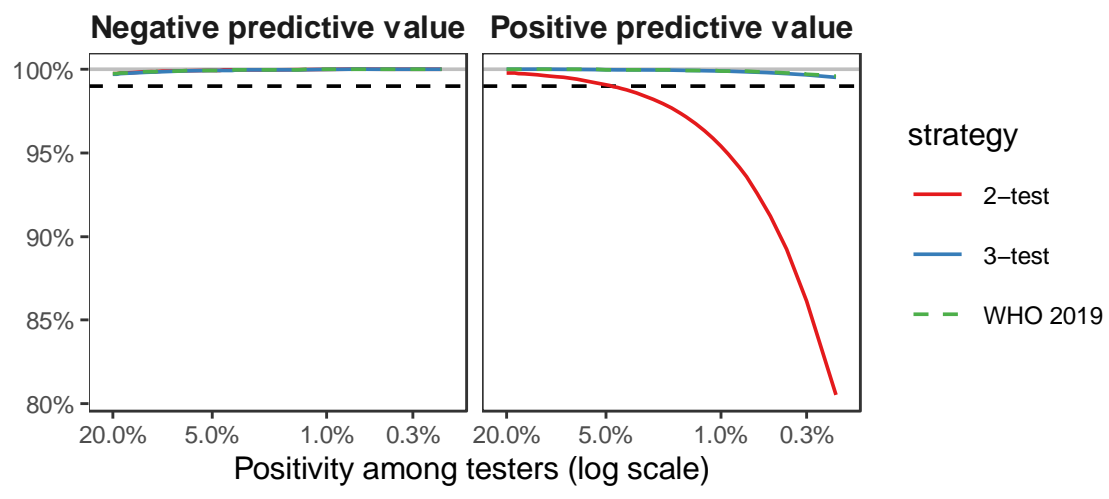

424 Figure 2. (A) Expected number of false negative, false positive, and inconclusive classifications

425 per 100,000 clients tested under alternative testing strategies for true prevalence among HIV

426 testing clients ranging from $20 \%$ to $0.2 \%$. (B) Negative predictive value (NPV) and positive

427 predictive value (PPV) for alternative testing strategies for prevalence ranging from $20 \%$ to

$428 \quad 0.2 \%$. Black dashed line indicates WHO target of 99\% PPV and 99\% NPV for HIV testing

429 strategies. 
medRxiv preprint doi: https://doi.org/10.1101/2021.03.31.21254700; this version posted April 6, 2021. The copyright holder for this preprint (which was not certified by peer review) is the author/funder, who has granted medRxiv a license to display the preprint in perpetuity.

It is made available under a CC-BY-NC 4.0 International license .

A

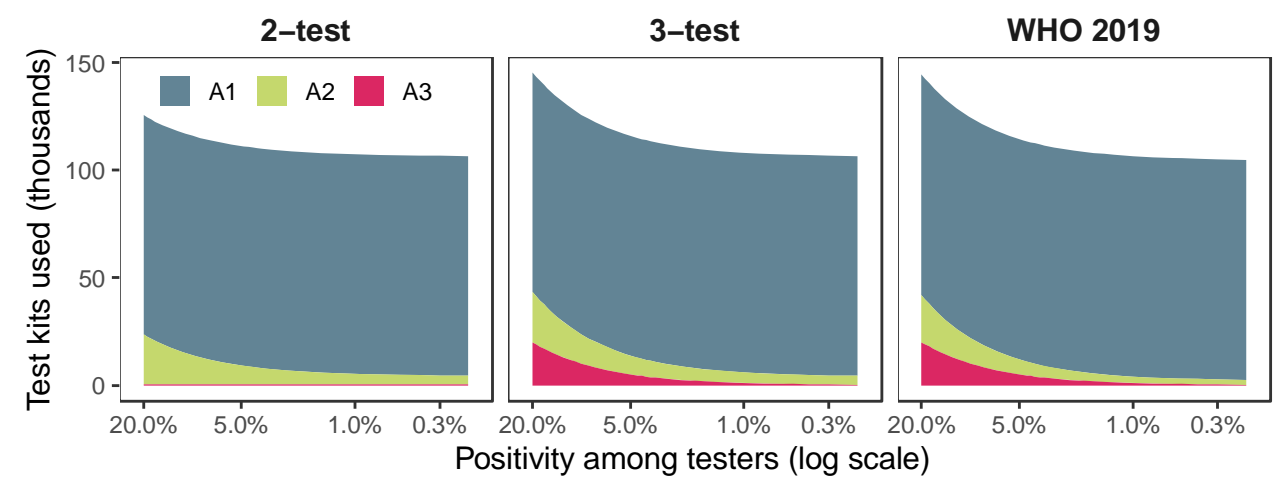

B

C Ratio of cost for WHO 2019 vs. 2-test
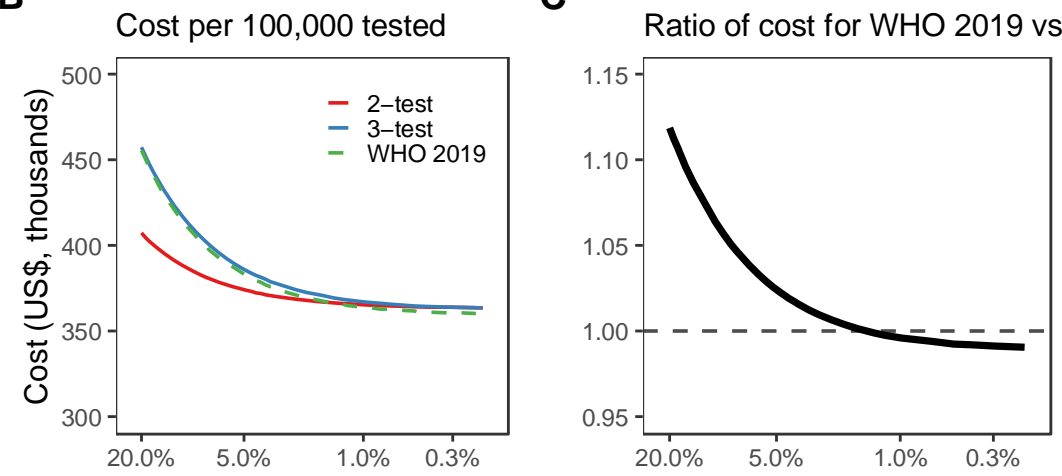

431 Figure 3. (A) Expected number of tests used by assay per 100,000 tested under the 2-test, 3-

432 test, and WHO 2019 testing strategies for positivity ranging from $20 \%$ to $0.2 \%$. (B) Estimated

433 cost per 100,000 tested as a function of HIV positivity for each strategy. (C) Ratio of total cost

434 under the WHO 2019 testing strategy versus the WHO 2015 2-test (high prevalence) strategy. 
A

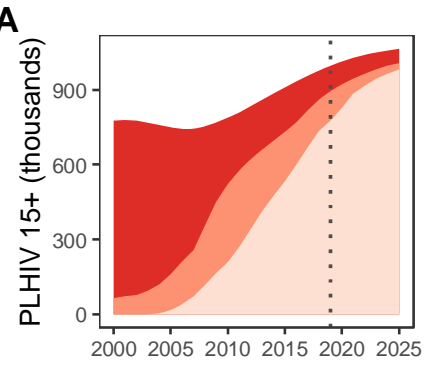

HIV positive, undiagnosed Aware of status On ART

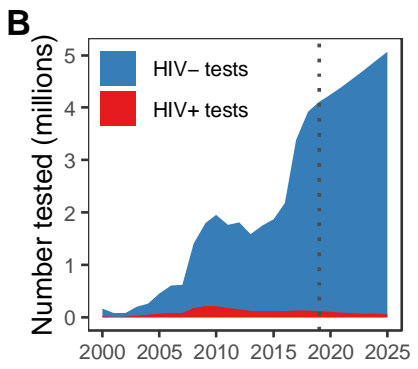

C

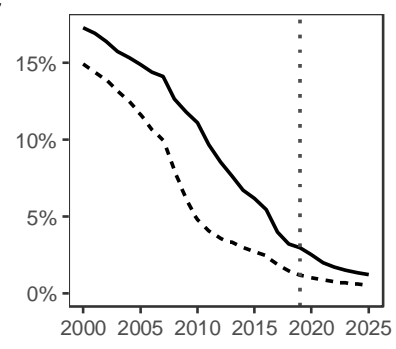

$\begin{array}{ll}\text { prevalence } & - \text { positivity } \\ \text { undiagnosed } & - \text { - yield }\end{array}$

436 Figure 4. Estimates and projections for the HIV population and HIV testing programme in

437 Malawi over period 2000 to 2025. (A) Total number of adult (15+ years) PLHIV stratified by

438 undiagnosed, aware of HIV status but untreated, and on ART. (B) Total number of HIV tests per

439 year amongst adults age 15+ and number of HIV-positive diagnoses. (C) HIV prevalence (light

440 red shaded area) and prevalence of undiagnosed HIV (dark red) in the adult population (15+

441 years), and HIV positivity amongst those tested for HIV (solid line) and the 'yield' of new

442 diagnoses (dotted line). 'Positivity' reflects the proportion of HTS clients who are positive

443 including both new diagnoses and those re-testing who are already aware or on ART. 'Yield' of

444 new diagnoses reflects the estimated proportion of HTS clients who being diagnosed for the first

445 time. (Source: Malawi 2020 UNAIDS Spectrum Estimates.) 
medRxiv preprint doi: https://doi.org/10.1101/2021.03.31.21254700; this version posted April 6, 2021. The copyright holder for this preprint (which was not certified by peer review) is the author/funder, who has granted medRxiv a license to display the preprint in perpetuity. It is made available under a CC-BY-NC 4.0 International license .

\section{A}

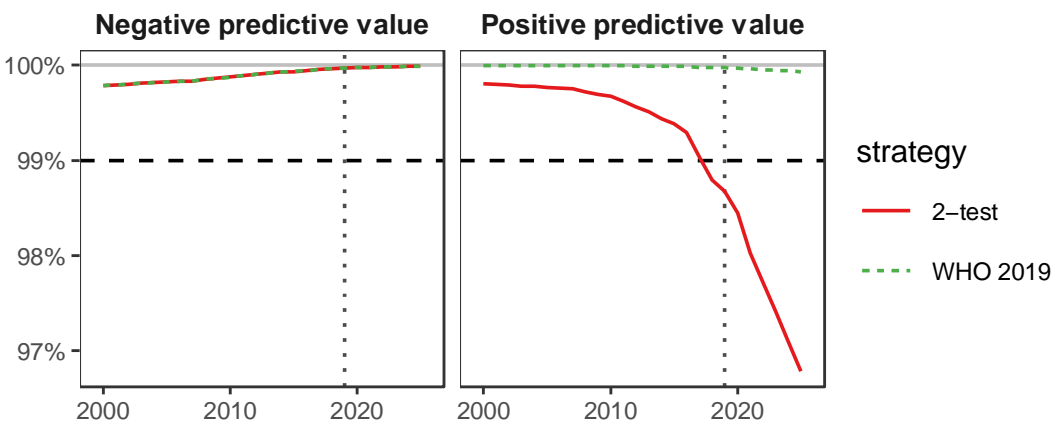

B

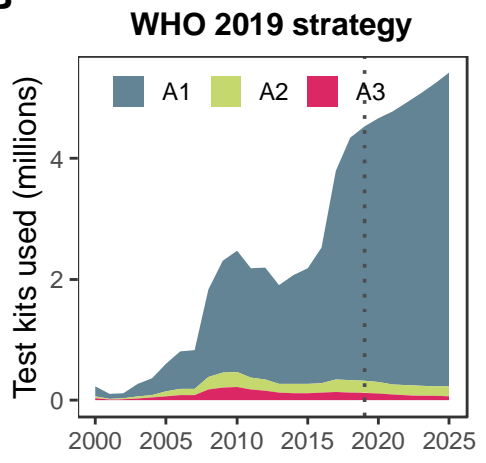

C

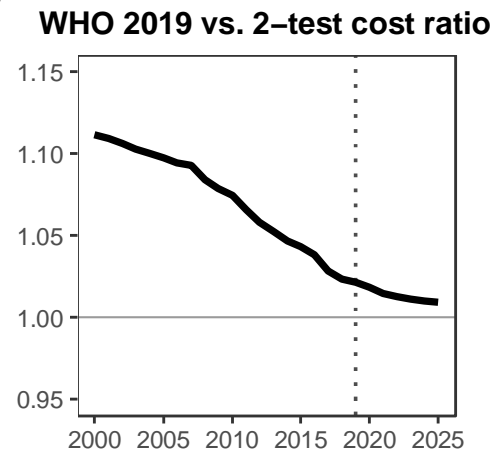

447 Figure 5. (A) Predicted negative predictive value (NPV) and positive predictive value (PPV) for

448 adults presenting to HIV testing in Malawi over period 2000 to 2025 using the WHO 2015 '2-test'

449 (high prevalence) strategy compared to the WHO 2019 recommended strategy and assuming

450 each assay performs at the minimum level required for WHO prequalification (99\% sensitivity,

$45198 \%$ specificity). (B) Expected number of tests used by the WHO 2019 strategy. (C) Ratio of

452 total cost per year for implementing the WHO 2019 strategy compared to the 2-test strategy.

453 Dotted vertical line denotes year 2019 reflecting the final year of HIV testing programme data

454 incorporated in estimates. Results for 2020 through 2025 reflect projections assuming HIV

455 testing rates for 2019 continue through 2025. 